\title{
MIGRASI PENDUDUK MENUJU DAERAH PINGGIRAN KOTA BANDUNG DAN IMPLIKASINYA TERHADAP KUALITAS LINGKUNGAN PERMUKIMAN
}

\author{
Iwan Setiawan \\ iwan4671@gmail.com \\ Jurusan Pendidikan Geografi FPIPS UPI \\ Jl. Setiabudi No 229 Bandung 40154
}

\begin{abstract}
ABSTRAK
Migrasi penduduk ke daerah pinggiran Kota Bandung membawa implikasi terhadap berkembangnya daerah pinggiran kota secara cepat. Perkembangan yang terjadi kadang tidak terkendali, sehingga muncul berbagai persoalan di daerah pinggiran kota, khususnya yang terkait dengan permukiman. Munculnya sejumlah permukiman yang tidak tertata dengan baik atau cenderung kumuh semakin banyak dijumpai. Persoalan tersebut tentu banyak terkait salah satunya dengan penduduk yang datang dan menetap di wilayah pinggiran, sehingga menarik untuk dikaji bagaimanakah implikasi migrasi penduduk terhadap kualitas lingkungan permukiman. Untuk mengkaji hal tersebut, digunakan metode survei dengan teknik pengambilan data melalui wawancara dan angket. Pengambilan sampel dilakukan secara purpossive dengan jumlah sampel yang sama antara migran desa-kota dengan migran kota-desa. Hasil penelitian menunjukkan adanya perbedaan karakteristik migran antara migran yang berasal dari pusat kota (migran kota-desa) dengan migran yang berasal dari desa-desa di sekitarnya maupun di daerah lainnya (migran desa-kota). Demikian halnya dengan faktor pendorong dan penarik, kedua tipe migran tersebut menunjukkan adanya perbedaan. Akibatnya, kualitas lingkungan permukiman migran yang berkembang di daerah pinggiran menunjukkan adanya perbedaan. Kualitas lingkungan permukiman migran desakota cenderung lebih rendah dibandingkan dengan kualitas lingkungan permukiman kota-desa.
\end{abstract}

Kata kunci: Migrasi, migran, migrasi desa-kota, migrasi kota-desa, kualitas lingkungan, permukiman, penduduk, pinggiran kota

\section{PENDAHULUAN}

\section{Latar Belakang}

Kota Bandung senantiasa mengalami perkembangan dari waktu ke waktu, termasuk perkembangan wilayahnya secara fisik. Secara horizontal, perkembangan fisik mulai dilaksanakan sejak tahun 1917 sampai dengan tahun 1987 ke daerah-daerah sekitarnya. Upaya tersebut dilakukan mengingat wilayah Kota Bandung lama hampir seluruhnya telah merupakan wilayah terbangun.

Kebijakan perluasan wilayah Kota Bandung membawa implikasi berkembangnya daerah pinggiran menjadi pusat-pusat permukiman, perdagangan dan industri baru. Permukiman tumbuh secara masif di sejumlah wilayah 
pinggiran akibat berbagai daya tarik pusat-pusat perekonomian dan kemudahan akan aksesibilitas. Pertumbuhan permukiman tersebut seringkali tidak terkendali dan pada beberapa bagian telah berkembang menjadi permukiman yang tidak tertata dengan baik, tampak kumuh, dan miskin akan fasilitas permukiman. Walaupun demikian, di bagian lainnya berkembang permukiman dengan kualitas yang lebih baik.

Kondisi permukiman di daerah pinggiran merupakan hasil dari penduduk yang datang dan menetap di wilayah tersebut. Migrasi penduduk menuju daerah tersebut dengan berbagai karakteristik demografi dan sosial ekonominya akan memberikan implikasi terhadap permukiman yang berkembang di wilayah pinggiran. Karena itu, menarik untuk dikaji bagaimanakah implikasi dari migrasi penduduk tersebut terhadap kualitas lingkungan di daerah pinggiran Kota Bandung.

Daerah pinggiran Kota Bandung memiliki daya tarik tersendiri bagi sejumlah penduduk untuk tinggal atau menetap. Beberapa dari daya tarik tersebut diantaranya harga lahan, aktivitas perekonomian, suasana lingkungan, dan lainlain. Berbagai daya tarik tadi menjadi magnet bagi penduduk dari daerah lainnya untuk pindah ke daerah ini sekaligus memberi kontribusi terhadap perkembangan dan permasalahan yang ada, khususnya masalah permukiman. Di beberapa wilayah telah dan mulai berkembang permukiman yang padat, tidak teratur, serta dengan fasilitas permukiman yang minim. Apapun keadaannya, kondisi tersebut dibentuk oleh penduduk setempat dan penduduk yang datang ke wilayah ini dengan berbagai tujuan. Karena itu, permasalahan yang dikaji dalam penelitian ini adalah: 1) bagaimanakah karakteristik migran desa-kota dan kota-desa di daerah pinggiran Kota Bandung? 2) apakah terdapat perbedaan faktor pendorong dan penarik antara migran desa-kota dan kota desa yang ada di daerah pingggiran Kota Bandung? 3) bagaimakah kualitas lingkungan migran desa-kota dan kota desa di daerah pinggiran Kota Bandung?

\section{Tujuan Penelitian}

Tujuan dari penelitian ini adalah: 1) mengidentifikasi karakteristik migran desa-kota dan kota-desa di daerah pinggiran Kota Bandung; 2) mengetahui ada tidaknya perbedaan faktor pendorong dan penarik antara migran desa-kota dan kota desa yang ada di daerah pingggiran Kota Bandung; 3) mengidentifikasi implikasi kualitas lingkungan migran desa-kota dan kota desa di daerah pinggiran Kota Bandung.

\section{METODE PENELITIAN}

Metode penelitian yang digunakan adalah metode survai. Metode ini dilakukan dengan mengambil sampel dari suatu populasi dan menggunakan kuesioner sebagai alat pengumpul data pokok (Singarimbun, 1987). Penentuan wilayah pinggiran dan pusat kota ditentukan terlebih dahulu untuk menentukan batasan geografis daerah penelitian. Untuk keperluan tersebut digunakan indikator penggunaan lahan, kepadatan penduduk, kepadatan bangunan, kepadatan fasilitas, 
dan pertambahan jumlah penduduk. Masing-masing indikator diberi skor dan kemudian ditentukan skor total untuk masing-masing kecamatan. Kecamatan yang memiliki skor sama dengan atau lebih besar dari 15 dianggap sebagai daerah pusat kota dan yang kurang dari 15 dianggap sebagai daerah pinggiran kota.

Hasil skoring menunjukkan bahwa Kecamatan yang termasuk kategori pinggiran kota adalah Kecamatan Cibiru, Arcamanik, Ujungberung, Rancasari, Cicadas, Margacinta, Bandung Kidul, Bojongloa Kidul, Bandung Kidul, Babakan Ciparay, Bandung Kulon, Sukasari dan Cidadap. Sisanya adalah kecamatankecamatan yang termasuk pusat kota.

Penentuan responden dilakukan secara purpossive yaitu rumah tangga migran dengan jumlah 200 rumah tangga. Responden dibagi ke dalam dua kategori yaitu rumah tangga migran yang berasal dari pusat kota (migran kota-desa) dan migran yang berasal dari desa (migran desa-kota). Jumlah responden masing kategori migran adalah 100 responden. Data yang dikumpulkan terdiri atas data primer dan data sekunder. Data primer dikumpulkan dengan cara wawancara dan angket. Teknik analisis yang digunakan adalah persentase dan tabulasi silang.

\section{HASIL DAN PEMBAHASAN}

\section{Karakteristik Migran di Daerah Pinggiran Kota Bandung}

Dalam kaitannya dengan kualitas lingkungan permukiman migran, maka karakteristik demografi, khususnya usia dan daerah asal migran perlu diketahui untuk melihat kecenderungan penduduk bermigrasi pada usia tertentu. Hasil penelitian sebelumnya terhadap migran desa-kota yang dilakukan oleh Suharso dkk (dalam Keban, 1995) dan migran kota-desa yang dilakukan oleh Sofranco (dalam Campbell, 1984) menunjukkan perbedaan karakteristik usia diantara kedua tipe migran tersebut. Pada migran desa-kota, kebanyakan migran berusia antara 15-24 tahun, sedangkan pada migran kota-desa memiliki persebaran usia yang lebih merata. Sementara itu, hasil penelitian yang dilakukan penulis tersaji dalam tabel berikut ini.

Tabel 1. Perbedaan Karakteristik Usia Migran Desa-Kota dan Kota-Desa di Daerah Pingggiran Kota Bandung

\begin{tabular}{ccc}
\hline $\begin{array}{c}\text { Kelompok } \\
\text { Usia Migran }\end{array}$ & $\begin{array}{c}\text { Migran Desa-Kota dan } \\
\text { Kota Desa (tahun) }\end{array}$ & $\begin{array}{c}\text { Migran Kota-Desa } \\
\text { (tahun) }\end{array}$ \\
\hline$<25$ & 18 & 4 \\
\hline $25-29$ & 31 & 8 \\
\hline $30-34$ & 19 & 22 \\
\hline $35-39$ & 15 & 17 \\
\hline $40-44$ & 11 & 22 \\
\hline$>44$ & 6 & 27 \\
\hline $\mathrm{N}(\%)$ & $100(100)$ & $100(100)$ \\
\hline
\end{tabular}

Hasil penelitian menunjukkan adanya perbedaan usia antara migran desa-kota dan kota desa. Migran desa-kota memiliki kelompok usia di bawah 25 tahun (usia muda atau mencari kerja) yang lebih besar jumlahnya (18\%) dibanding dengan 
migran kota-desa yang proporsi kelompok usia mudanya lebih kecil (4\%). Sementara itu, pada kelompok usia di atas 45 tahun, migran desa-kota memiliki persentase yang lebih kecil $(6 \%)$ dibanding dengan migran kota-desa $(27 \%)$. Perbedaan karakteristik usia migran dapat dipahami dalam kaitannya dengan alasan mereka pindah. Migran desa-kota umumnya memiliki alasan ekonomi atau mencari pekerjaan di daerah perkotaan. Hal ini berarti mereka merupakan penduduk usia muda atau penduduk usia mencari kerja.

Karakteristik migran lainnya terkait dengan daerah asal yang memberikan gambaran tentang kekuatan pengaruh Kota Bandung, khususnya daerah pinggiran kota, terhadap daerah lainnya. Gambaran tentang komposisi migran berdasarkan daerah asal dapat dilihat pada tabel berikut ini.

Tabel 2. Daerah Asal Migran Desa-Kota dan Kota Desa di Daerah Pingggiran Kota Bandung

\begin{tabular}{lcc}
\hline Daerah Asal Migran & $\begin{array}{c}\text { Migran Desa-Kota } \\
\text { dan Kota Desa }\end{array}$ & Migran Kota-Desa \\
\hline $\begin{array}{l}\text { 1. Wilayah Pembangunan } \\
\text { Bandung Raya }\end{array}$ & 32 & 45 \\
\hline 2. Jawa Barat & 28 & 39 \\
\hline 3. Luar Jawa Barat & 40 & 16 \\
\hline N (\%) & $100(100)$ & $100(100)$ \\
\hline
\end{tabular}

Hasil penelitian menunjukkan bahwa wilayah pengaruh Kota Bandung tidak hanya sebatas wilayah Jawa Barat, melainkan wilayah-wilayah lainnya di luar Jawa Barat (Jawa Tengah, Jawa Timur dan Sumatera). Bahkan persentase migran dari luar Jawa Barat pada kelompok migran desa-kota paling tinggi (40\%) dibandingkan dengan daerah asal lainnya. Ini berarti bahwa kekuatan jarak dalam menentukan volume migrasi seperti dalam hukum migrasi yang dikemukakan Lee (1966) tidak berlaku untuk kasus migrasi menuju daerah pingggiran Kota Bandung.

\section{Faktor pendorong}

Di negara-negara berkembang seperti halnya Indonesia, daya dorong dari daerah asal sangat kuat mempengaruhi migran meninggalkan daerah asal (McGee, 1971). Daya dorong dari daerah asal yang terjadi karena kecilnya kemungkinan untuk mendapatkan tingkat kesejahteraan yang diinginkan menjadi pemicu yang cukup besar untuk meninggalkan daerah asal.

Kenyataan tersebut sebenarnya pernah berkembang di negara maju pada awal perkembangan industrinya. Eversley (dalam Lewis, 1982) menceritakan adanya keengganan buruh-buruh di desa bekerja pada sektor pertanian karena prospeknya yang lebih besar jika bekerja di sektor industri dan pertambangan.

Berdasarkan hasil penelitian ini sedikitnya terdapat tiga alasan utama seseorang meninggalkan daerah asalnya yaitu alasan yang berkaitan dengan pemenuhan kebutuhan akan rumah, kondisi lingkungan dan ekonomi. Gambaran tentang alasan migran meninggalkan daerah asalnya dapat dilihat pada tabel 3 . 
Tabel 3. Alasan/Motivasi Migran Meninggalkan Daerah Asal

\begin{tabular}{lcc}
\hline Alasan/Motivasi & $\begin{array}{c}\text { Migran Desa-Kota } \\
\text { dan Kota Desa }\end{array}$ & Migran Kota-Desa \\
\hline 1. Rumah & 6 & 25 \\
\hline 2. Lingkungan & 1 & 18 \\
\hline 3. Ekonomi & 93 & 57 \\
\hline $\mathrm{N}(\%)$ & $100(100)$ & $100(100)$ \\
\hline
\end{tabular}

Tabel di atas menunjukkan bahwa faktor yang mendorong migran desa-kota meninggalkan daerah asal sebagian besar $(93 \%)$ adalah karena alasan ekonomi. Alasan ekonomi juga menjadi faktor pendorong paling besar migran kota-desa bermigrasi ke daerah pinggiran kota, namun persentasenya jauh lebih rendah (57\%) dibanding migran desa-kota. Bagi sebagian migran kota-desa, faktor kebutuhan akan rumah dan lingkungan menjadi alasan mereka meninggalkan pusat kota yang sudah tidak nyaman lingkungannya dan harga rumah dan lahan sudah terlampau tinggi.

Hasil penelitian tersebut sesuai dengan apa yang dikemukakan oleh Sofranco (dalam Campbell, 1984) yang menyimpulkan bahwa migrasi kota-desa dicirikan oleh lebih kecilnya motivasi untuk mencari pekerjaan dibanding migran desakota. Ketidakpuasan terhadap tempat tinggal di daerah asal (pusat kota) menjadi besar karena perubahan karakteristik personal menyangkut perubahan kondisi sosial-ekonomi dan perubahan persepsi tentang rumah dan lingkungan. Perubahan jumlah anggota keluarga dan siklus hidup membutuhkan tempat tinggal yang lebih nyaman dan lebih luas. Perubahan di daerah asal (pusat kota) juga terjadi pada karakteristik lokasional atau karakteristik lingkungan karena meningkatnya polusi udara, kebisingan dan lain-lain.

\section{Faktor Penarik}

Menurut Sofranco (dalam Campbell, 1984) motivasi dan keputusan migrasi sebagian berhubungan dengan daerah asal dan sebagian lagi berhubungan dengan daerah tujuan. Migrasi bisa terjadi jika kefaedahan di daerah tujuan lebih besar dibandingkan dengan di daerah asal. Dengan demikian, keputusan yang diambil tidak hanya didasarkan atas penilaian tentang daerah asal tetapi juga identifikasi dan penilaian berbagai karakteristik daerah tujuan.

Beberapa karakteristik yang menjadi daya tarik daerah pinggiran adalah menyangkut kemungkinan perluasan rumah, lingkungan yang masih nyaman dan aman, peluang membuka usaha baru, peluang kerja dan peningkatan pendapatan. Secara umum kefaedahan tersebut dapat dikelompokkan ke dalam tiga klasifikasi utama, yaitu rumah, lingkungan dan kefaedahan ekonomi.

Tabel 4. Penilaian terhadap Daya Tarik Daerah Tujuan

\begin{tabular}{lcc}
\hline \multicolumn{1}{c}{ Alasan/Motivasi } & $\begin{array}{c}\text { Migran Desa-Kota } \\
\text { dan Kota Desa }\end{array}$ & Migran Kota-Desa \\
\hline 1. Rumah & 3 & 25 \\
\hline 2. Lingkungan & 1 & 11 \\
\hline 3. Ekonomi & 96 & 65 \\
\hline $\mathrm{N}(\%)$ & $100(100)$ & $100(100)$ \\
\hline
\end{tabular}


Berdasarkan kedua tipe migran memiliki penilaian dan motivasi yang sama tentang daerah pinggiran Kota Bandung yaitu ekonomi. Bagi mereka daerah pinggiran masih menyompan banyak peluang untuk bekerja atau melakukan kegiatan usaha. Sekitar 18 jenis industri berskala besar, terutama industri tekstil, ada di wilayah ini, sehingga menjadi daya tarik bagi migran untuk mencari kerja. Walaupun demikian, perbedaannya tetap ada yaitu persentase migran desa-kota yang beralasan untuk memperoleh rumah dan lingkungan yang lebih baik tampak lebih terlihat.

Fenomena migrasi dari pusat kota ke daerah pinggiran terjadi karena didukung oleh perkembangan teknologi transportasi dan komunikasi serta ekspansi berbagai aktivitas ekonomi dari pusat kota sesuai dengan yang dikemukakan Frey (1984) tentang pandangan restruksturisasi regional dan pandangan dekonsentrasi. Pandangan restrukturisasi regional menjelaskan bahwa pergantian penduduk di daerah perkotaan mencerminkan adanya perubahan organisasi produksi. Perubahan tersebut terlihat dengan berpindahnya berbagai industri dari pusat kota ke daerah pinggiran yang didukung oleh adanya inovasi dalam produksi, transportasi dan komunikasi. Pandangan dekonsentrasi menjelaskan bahwa hilangnya hambatan geografis memungkinkan adanya dekonsentrasi pekerja karena relokasi dan ekspansi berbagai jenis kegiatan usaha ke daerah pinggiran.

\section{Perbedaan Kualitas Lingkungan Permukiman Migran Desa-Kota dengan Kota Desa}

Secara geografis, umumnya migran desa-kota terkonsentrasi di sekitar pusat aktivitas ekonomi seperti di Kecamatan Ujungberung. Kondisi rumah mereka umumnya tidak layak dengan luas rumah yang sempit, kepadatan hunian yang tinggi, sanitasi yang jelek, lokasi rumah dekat saluran air yang telah tercemar, dan umumnya tidak memiliki pekarangan dengan luas yang maadai. Lain halnya migran kota-desa yang umumnya tinggal pada kompleks perumahan dengan kualitas yang relatif lebih baik dibanding dengan migran desa-kota.

Dari hasil rerata perhitungan rerata skor komponen kualitas lingkungan perumahan menunjukkan bahwa terdapat perbedaan rerata skor kualitas lingkungan perumahan antara migran desa-kota dengan migran kota-desa. Rerata skor migran kota-desa lebih tinggi dibanding rerata skor migran kota-desa. Hal ini menunjukkan bahwa kualitas lingkungan permukiman migran kota-desa lebih baik dibandingkan dengan migran desa-kota.

Tabel 5. Rerata Skor dan Kualitas Lingkungan Permukiman Migran Desa-Kota dan Migran Kota-Desa

\begin{tabular}{cccccc}
\hline Tipe Migran & $\mathbf{N}$ & $\begin{array}{c}\text { Rerata } \\
\text { Skor }\end{array}$ & \multicolumn{3}{c}{ Kualitas Permukiman (\%) } \\
\cline { 3 - 6 } & & Jelek & Sedang & Baik \\
\hline Migran Desa-Kota & 100 & 20,5 & 57 & 38 & 5 \\
\hline Migran Kota-Desa & 100 & 31,5 & 5 & 36 & 59 \\
\hline
\end{tabular}

Berdasarkan tabel di atas tampak adanya perbedaan kualitas lingkungan permukiman antara kedua tipe migran. Perbedaan kualitas lingkungan permukiman diantara kedua tipe migran tersebut sangat terkait dengan perbedaan kondisi sosial-ekonomi migran, dilihat dari pendidikan, pendapatan, kebiasaan 
keluarga, dan matapencaharian. Migran kota-desa terbukti memiliki keadaan sosial-ekonomi yang lebih baik, sehingga mereka mampu tinggal pada rumah dan lingkungannya yang lebih baik.

\section{SIMPULAN}

Permasalahan yang terkait dengan kualitas lingkungan di daerah pinggiran Kota Bandung berkaitan dengan penduduk yang datang atau bermigrasi ke wilayah ini. Setidaknya ada dua tipe migran berdasarkan daerah asalnya, yaitu migran yang berasal dari pusat Kota Bandung (Migran Kota-Desa) dan migran yang berasal dari desa (Migran Desa-Kota).

Kedua tipe migran tersebut memiliki karakteristik yang berbeda dilihat dari usia, alasan pindah, faktor pendorong dan faktor penarik yang membuat mereka melakukan migrasi. Usia migran desa-kota cenderung lebih banyak pada usia produktif, terutama pada kelompok usia 25-29 tahun, sementara pada migran kota-desa lebih tersebar pada kelompok usia lainnya. Walaupun alasan pindah sama-sama didominasi oleh alasan ekonomi, tetapi pada migran kota-desa persentase alasan non ekonomi jauh lebih besar. Ketertarikan sebagian migran kota-desa, lebih pada kemungkinan pemilikan rumah yang lebih baik dan dengan harga lahan yang lebih rendah, sedangkan sebagian lainnya tertarik karena alasan lingkkungan yang lebih nyaman dibandingkan dengan pusat kota.

Akibat perbedaan-perbedaan tersebut, kualitas lingkungan permukiman yang terbentuk menunjukkan adanya perbedaan. Kualitas lingkungan permukiman migran kota-desa tampak lebih baik dibandingkan dengan migran desa-kota.

\section{DAFTAR PUSTAKA}

Blaang, Jemabut. (1986). Perumahan dan Permukiman sebagai Kebutuhan Pokok. Jakarta: Yayasan Obor Indonesia.

Campbell, Rex R. dan Lorraine Garkovich. (1984). Turnaround Migration as an Episode of Collective Behaviour. Kentucky: Department of Sociology University.

Frey, William H. (1987). Migration and Depopulation of Metropolis: Regional Restructuring or Rural Renaissance? Reprinted from American Sociological Review 52 (April,1987). Page 240-257. The University of Michigan University Population studies Center

Lee, Everett, S. (1995). Teori Migrasi. Seri Terjemahan. Yogyakarta: Pusat Penelitian Kependudukan UGM.

Mc Gee, T.G. (1971). The Urbanization Process in The Third World (Explanation in Search of Theory). London: The Camelot Press Ltd 